\title{
Skłonność do pękania gorącego złączy spawanych z nadstopu niklu Inconel 617
}

\author{
The tendency to hot cracking of the welded joints \\ of nickel superalloy Inconel 617
}

\begin{abstract}
Streszczenie
W pracy przedstawiono wyniki oceny skłonności do pękania gorącego nadstopu niklu Inconel 617. Badania przeprowadzono na blachach o grubości 1, 3 oraz $5 \mathrm{~mm}$ wykorzystując próbę Houldcrofta w warunkach zmiennej sztywności złącza. W próbie Houldcrofta, używając nietopliwej elektrody w osłonie gazów obojętnych, wykonano przetopienia stopu Inconel 617 z materiałem dodatkowym i bez materiału dodatkowego. W próbie wyznaczono wskaźnik A rozumiany jako stosunek długości pęknięcia do długości próbki, który jest wyrażany w procentach. Badania zostały uzupełnione o analizę metalograficzną i fraktograficzną, mikroanalizę składu chemicznego EDS z powierzchni pęknięcia oraz powierzchni prostopadłej do kierunku spawania. Uzyskane wyniki pozwoliły na opisanie mechanizmu pękania złączy spawanych z nadstopu niklu Inconel 617.
\end{abstract}

Słowa kluczowe: nadstopy niklu; pękanie gorące; złącza spawane z nadstopu niklu Inconel 617; próba Houldcrofta; materiały dla energetyki

\begin{abstract}
The paper presents the results of the propensity of hot cracking of the nickel superalloy Inconel 617 . The tests were carried out on nickel sheets with a thickness of 1,3 and $5 \mathrm{~mm}$ using a Houldcroft's test in variable stiffness of the welded joint. In Houldcroft's test by using tungsten electrode in inert gas, remelting alloy Inconel 617 with additional material without additional material were made. In test the indicator A was designated, understood as the ratio of the crack length to the length of the sample, which is expressed as a percentage. Studies have been complemented by metallographic and fractography analysis, also made microanalysis of the chemical composition EDS of the crack surface and the surface, which is perpendicular to the direction of welding. The results allowed to describe the hot cracking mechanism of welded joints of nickel superalloy Inconel 617.
\end{abstract}

Keywords: superalloys of nickel; hot cracking; welded joints of Inconel 617; Houldcroft's test; materials for Power Plant

\section{Wstęp}

Nieustanny rozwój przemysłu energetycznego, lotniczego i kosmicznego zmusza projektantów oraz konstruktorów do zastosowania innowacyjnych materiałów, które wykazują wysokie właściwości wytrzymałościowe. Obecnie duże zainteresowanie wzbudzają nadstopy niklu z powodu ich wysokiej odporności korozyjnej w środowisku chlorków, związków siarki oraz tlenu, wytrzymałości na pełzanie w wysokiej temperaturze, a także stabilności mikrostruktury, która jest czynnikiem decydującym o stabilności właściwości wytrzymałościowych podczas długotrwałej eksploatacji. Jedyną istniejącą wadą $w$ nadstopach niklu jest ich duża cena, natomiast jest ona zrekompensowana unikalnymi właściwościami materiału [1 $\div 4$ ].

Jednym z częściej stosowanych nadstopów jest niklowochromowo-kobaltowo-molibdenowy Inconel 617. Zastosowane dodatki stopowe w postaci molibdenu oraz kobaltu zwięk- szają właściwości mechaniczne wpływając na roztworowy charakter umocnienia nadstopu. Wprowadzenie chromu i aluminium pozwala zwiększyć odporność na utlenianie w podwyższonej temperaturze. Dzięki obecności chromu w nadstopie wydzielają się węgliki typu $\mathrm{M}_{2} \mathrm{C}_{3}$, a w połączeniu z molibdenem tworzą się węgliki $\mathrm{M}_{23} \mathrm{C}_{6}$, które poprawiają właściwości mechaniczne. W związku z kombinacją wysokiej wytrzymałości i odporności na utlenianie, Inconel 617 może być stosowany jako materiał na odpowiedzialne elementy kotłów do spalania biomasy, w budowie silników lotniczych i reaktorów jądrowych. Istotną wadą wielkoskładnikowego nadstopu niklu Inconel 617 jest skłonność do pękania podczas spawania.

Najczęściej występującymi pęknięciami są pęknięcia gorące (krystalizacyjne) w obszarze spoiny, jednak większym zagrożeniem są pęknięcia w strefie wpływu ciepła (SWC),

Mgr inż. Natalia Konieczna; dr hab. inż. Janusz Adamiec, prof. PŚl - Politechnika Śląska.

Autor korespondencyjny/Corresponding author: natalia.konieczna@polsı.pl 
ponieważ są problematyczne do ujawnienia dostępnymi me-

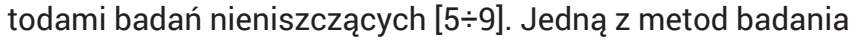
skłonności do pęknięć nadstopów niklu jest próba Houldcrofta polegająca na przetapianiu płytki z badanego materiału elektrodą nietopliwą w osłonie gazu obojętnego (TIG) z materiałem dodatkowym lub bez niego. Cechą charakterystyczną tej metody są nacięcia na płytkach (rys. 1) symulujące zmienną sztywność elementu podczas spawania. Jako miernik odporności nadstopu przyjęto wartość wskaźnika A, który jest definiowany jako stosunek długości pęknięcia do długości próbki i wyrażony jest w procentach [10].

W dostępnej literaturze niewiele jest informacji dotyczących mechanizmu pękania gorącego nadstopu niklu Inconel 617, a zwłaszcza właściwości metalurgicznych spoin podczas krystalizacji. W związku z powyższym konieczne jest prowadzenie badań w zakresie oceny skłonności nadstopu Inconel 617 do pęknięć gorących wraz z wyjaśnieniem przyczyn powstania pęknięć. W badaniach szczególną uwagę zwrócono na miejsca, w których ujawniły się pęknięcia.

Celem pracy była ocena skłonności złączy spawanych z nadstopu niklu Inconel 617 do pękania gorącego. W pracy przedstawiono wyniki badań z wykonanej próby Houldcrofta, która została uzupełniona analizą metalograficzną z powierzchni pęknięcia oraz z powierzchni prostopadłej do kierunku przetapiania, a także wykonano analizę fraktograficzną przełomu.

\section{Materiał i metodyka badań}

Materiałem do badań były próbki w postaci płytek z nadstopu niklu Inconel 617, którego skład chemiczny został przedstawiony w tablicy I.

Badania skłonności do pękania gorącego przeprowadzono na próbkach o grubości $1 \mathrm{~mm}, 3 \mathrm{~mm}$ oraz $5 \mathrm{~mm}$. Sposób przygotowania płytek do próby Houldcrofta do przetapiania bez materiału dodatkowego pokazano na rysunku $1 \mathrm{a}$, natomiast na rysunku 1b przedstawiono sposób przygotowana próbek do przetapiania z materiałem dodatkowym. Jako materiał dodatkowy stosowano druty spawalnicze z nadstopu niklu Inconel 617 o średnicy $\varphi$ 2,4 mm.

Parametry wykonanego przetapiania metodą TIG przedstawiono w tablicy II i zostały dobrane tak, aby uzyskać pełny przetop. Przykładowe zdjęcia próbek z pęknięciami zostały przedstawione na rysunku 2. Próbki do badań zostały wycięte prostopadle do kierunku spawania, aby ujawnić wszystkie strefy złącza. Wycięte próbki były szlifowane i polerowane na pastach diamentowych. Aby ujawnić strukturę materiału próbki były trawione elektrolitycznie w odczynniku Lucasa. Analizę morfologii pęknięcia prowadzono na powstałym przełomie.

Badania metalograficzne i fraktograficzne przeprowadzono na stereoskopowym mikroskopie świetlnym Olympus SZX 9 przy powiększeniach do 50x (SM) oraz na mikroskopie świetlnym Olympus GX-71 w technice obserwacji w polu jasnym (LM) (rys. 2, rys. 4). Wykonano również badania przełomu i struktury przy dużych powiększeniach oraz mikroanalizę składu chemicznego za pomocą elektronowego mikroskopu skaningowego JEOL JCM-6000 Neoscope II z przystawką EDS (SEM). Rejestracji obrazów dokonano w technice elektronów wtórnych SE, przy powiększeniu do 1000x i napięciu przyspieszającym wiązkę elektronów $15 \mathrm{keV}$ (rys. 5 i rys. 6).
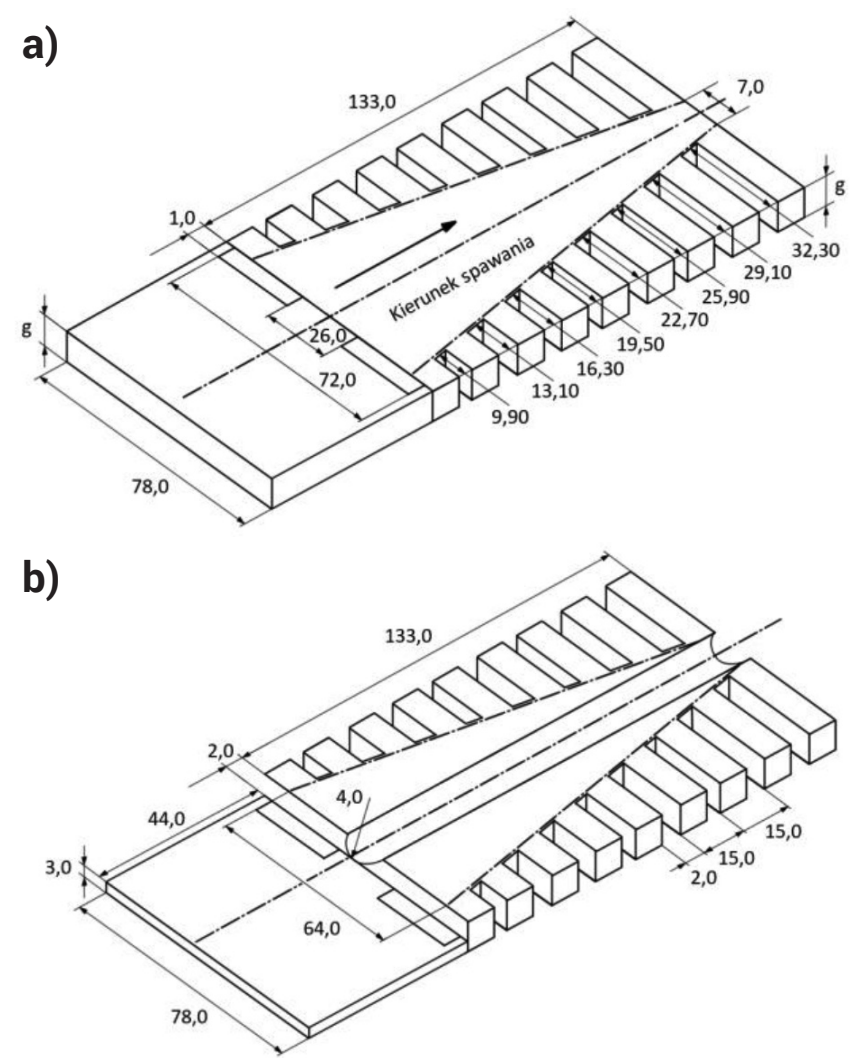

Rys. 1. Płytki do próby Houldcrofta: a) przetapianie bez materiału dodatkowego; b) przetapianie z materiałem dodatkowym [10]

Fig. 1. The plates for Houldcroft's test: a) remelting without additional material; b) remelting with additional material [10]

Tablica I. Skład chemiczny nadstopu niklu Inconel $617, \%$ mas

Table I. Chemical composition of the superalloy Inconel $617, \%$ mass

\begin{tabular}{|c|c|c|c|c|c|c|c|}
\hline Materiał & $\mathrm{Ni}$ & $\mathrm{Cr}$ & Co & Mo & Al & C & $\mathrm{Fe}$ \\
\hline \multirow{3}{*}{ Inconel 617} & $\min .44,5$ & $20,0 \div 24,0$ & $10,0 \div 15,0$ & $8,0 \div 10,0$ & $0,8 \div 1,5$ & $0,05 \div 0,15$ & $\max .3,0$ \\
\hline & Mn & $\mathrm{Si}$ & S & $\mathrm{Ti}$ & $\mathrm{Cu}$ & B & \\
\hline & $\max .1,0$ & $\max .1,0$ & $\max .0,015$ & $\max .0,6$ & $\max .0,5$ & $\max .0,006$ & \\
\hline
\end{tabular}

Tablica II. Parametry przetapiania nadstopu niklu Inconel 617

Table II. The parameters of remelting the nickel superalloy Inconel 617

\begin{tabular}{|c|c|c|c|c|c|c|}
\hline $\mathrm{g}[\mathrm{mm}]$ & $\begin{array}{l}\text { Natężenie prądu } \\
\text { [A] }\end{array}$ & Napięcie łuku [V] & $\begin{array}{l}\text { Prędkość } \\
\text { spawania } \\
\text { [cm/min] }\end{array}$ & $\begin{array}{c}\text { Przepływ gazu } \\
\text { [l/min] }\end{array}$ & $\begin{array}{c}\text { Średnica dyszy } \\
\text { gazowej }\end{array}$ & $\begin{array}{c}\text { Symbol } \\
\text { i średnica elektro- } \\
\text { dy wolframowej }\end{array}$ \\
\hline 1 & 30 & \multirow{3}{*}{25} & \multirow{3}{*}{16} & \multirow{3}{*}{12} & \multirow{3}{*}{12} & \multirow{3}{*}{$\begin{array}{l}\text { WTh 20; } \\
\text { 2,4 mm }\end{array}$} \\
\hline 3 & 80 & & & & & \\
\hline 5 & 140 & & & & & \\
\hline
\end{tabular}




\section{Wyniki i ich dyskusja}

Na podstawie przeprowadzonej próby Houldcrofta stwierdzono, iż parametry przetapiania dla próbki o grubości $1 \mathrm{~mm}$ (IN_1_P) zostały dobrane poprawnie, ponieważ nie ujawniono pęknięć zarówno w spoinie, jak i w SWC (rys.2 i rys. $2 b$ ). W próbce o grubości $3 \mathrm{~mm}$ po przetopieniu (IN_3_P) ujawniono pęknięcie przy pomocy mikroskopu stereoskopowego. Pęknięcie zostało zainicjowane od strony początku przetapiania i ma długość 10,5 mm. W próbce IN_3_N zaobserwowano pęknięcie od strony początku procesu napawania płytki (rys. 2c, rys. 2d), o długości 17,5 mm. W próbce o grubości $5 \mathrm{~mm}$ po przetapianiu i napawaniu (IN_5_P,IN_5_N) zaobserwowano niewielkie pęknięcia, które występowały zarówno przy początku wykonanego przetopienia, jak i w środkowej długości płytki i ich długość wynosiła sumarycznie 5 mm dla IN_5_P i 6 mm dla IN_5_N (rys. 2e, rys. 2f).

Analiza wyników próby Houldcrofta (rys. 3) pozwala stwierdzić, iż nadstop niklu Inconel 617 w warunkach zmiennej sztywności złącza podczas przetapiania bez materiału dodatkowego jest mniej skłonny do pękania gorącego o ok. $40 \%$ w stosunku do napawania dla blachy o grubości $3 \mathrm{~mm}$, a dla grubości blachy wynoszącej $5 \mathrm{~mm}$ o ok. 17\%. Napawanie jest procesem, w trakcie którego dochodzi do nierównomiernego nagrzewania i chłodzenia materiału, jednocześnie zwiększa się rozszerzalność cieplna materiału i wskutek tego występują znaczne naprężenia powodujące zwiększoną skłonność do pękania nadstopu niklu. a)

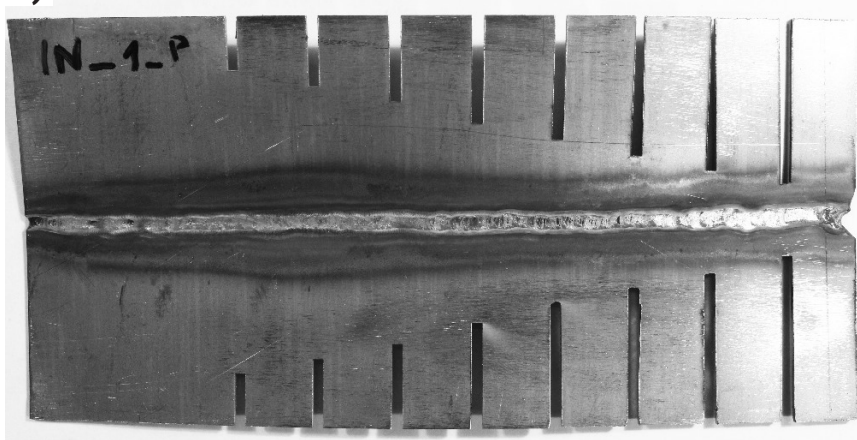

b)

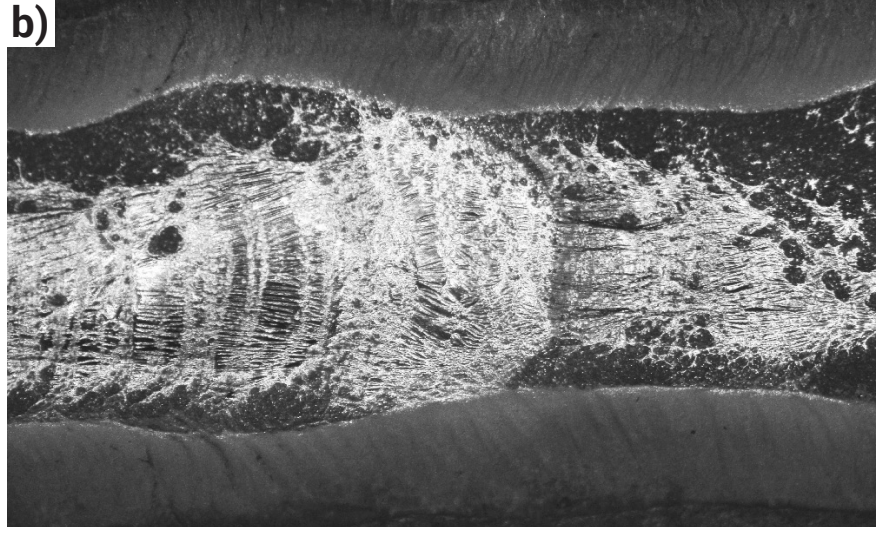

d)

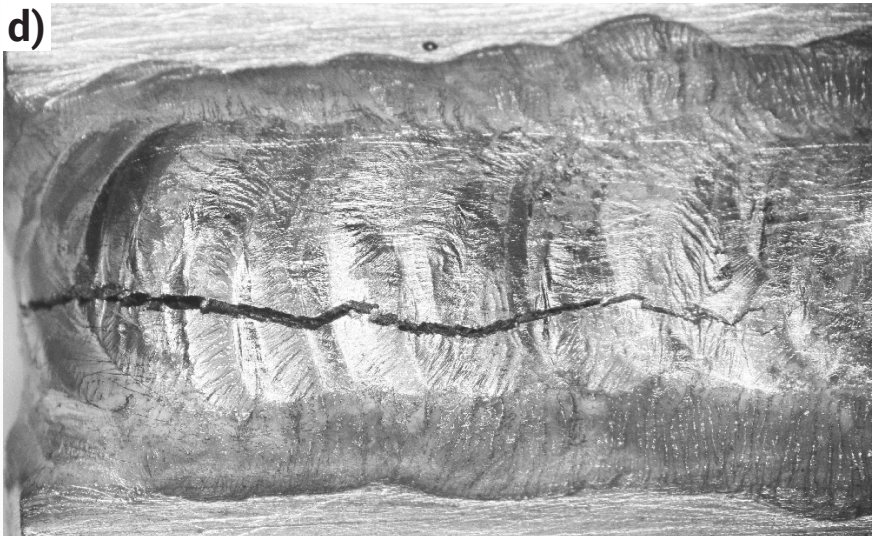

e)
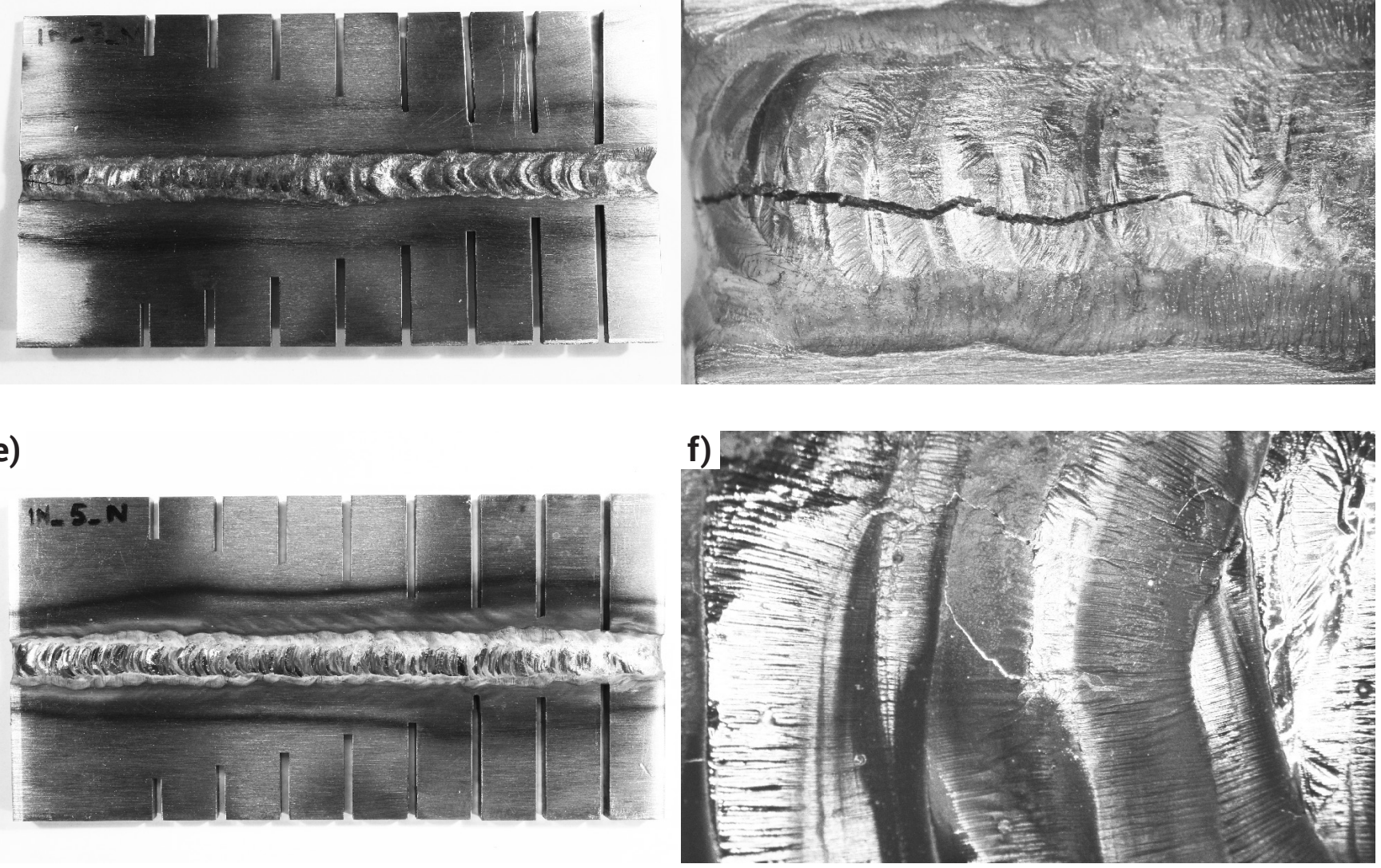

Rys. 2. Badania metalograficzne po wykonanej próbie Houldcrofta, SM: a) przetopiona próbka o grubości 1 mm (IN_1_P); b) spoina próbki IN_1_P; c) napawana próbka o grubości $3 \mathrm{~mm}$ (IN_3_N); d) pęknięcie w napoinie próbki IN_3_N; e) napawana próbka o grubości 5 mm (IN_5_N); f) pęknięcie w napoinie próbki IN_5_N

Fig. 2. The results of metallographic research, which was done after Houldcroft's test, SM: a) remelted sample with a thickness of $1 \mathrm{~mm}$ $\left.\left(I N \_1 \_P\right) ; b\right)$ the weld of sample IN_1_P; c) weld overlay sample with thickness of $3 \mathrm{~mm}($ IN_3_N); d) the crack in the overlay weld of the sample IN_3_N; e) weld overlay sample with a thickness of $5 \mathrm{~mm}\left(\mathrm{IN} \_5 \_N\right)$; f) the crack in the overlay weld of the sample IN_5_N 


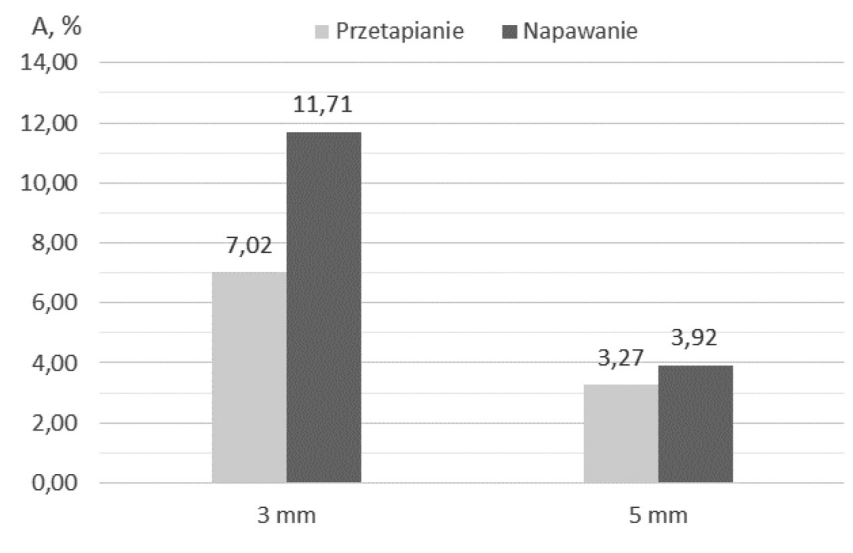

Rys. 3. Wyniki próby Houldcrofta próbek o grubości $3 \mathrm{~mm}$ i $5 \mathrm{~mm}$ nadstopu niklu Inconel 617

Fig. 3. The results of Houldcroft's test for $3 \mathrm{~mm}$ and $5 \mathrm{~mm}$ thickness plates of superalloy Inconel 617

Badania mikrostruktury przeprowadzono na zgładzie metalograficznym próbki IN_3_N zawierającym pęknięcie, wykonanym prostopadle do osi powstałej napoiny. $\mathrm{Na}$ podstawie wykonanych badań metalograficznych (rys. 4) stwierdzono, że osnowa y nadstopu niklu charakteryzuje się licznymi wydzieleniami (rys. 4a), które występują wewnątrz osnowy jak po granicach ziarn. Na podstawie przeprowadzonej mikroanalizy składu chemicznego stwierdza się, że ujawnione wydzielenie po granicy ziarna stanowi węglik bogaty $w$ tytan, natomiast jasne wydzielenia wewnątrz osnowy to węgliki wtórne bogate w chrom. W obszarze linii wtopienia zaobserwowano rozrost ziarn, charakterystyczny dla oddziaływania cyklu cieplnego podczas spawania (rys. 4b) i nie stwierdzono pęknięć segregacyjnych, a także nadtapiania osnowy $\gamma$. Materiał przetopienia charakteryzuje się wydłużonymi krystalitami (rys. 4c). $\mathrm{Na}$ podstawie analizy struktury (rys. 4b, rys. 4c) stwierdzono, iż stopiony materiał krystalizuje narastająco zgodnie z kierunkiem odprowadzonego ciepła. Na rysunku 4d obserwowano powstałe mostki pęknięć tworzące się po graniach ziarn-międzykrystalicznie, obejmujące swym zasięgiem powierzchnię kilkunastu ziarn. Materiał przy powstałym pęknięciu utracił swoją zdolność do odkształcenia plastycznego i w ten sposób została zainicjowana propagacja nieciągłości z powodu powstania najprawdopodobniej kruchych warstewek na granicach ziarn. Przeprowadzone badania morfologii pęknięcia na elektronowym mikroskopie skaningowym (rys. 5) wykazały, że jest to pękanie gorące, przebiegające wzdłuż wykonanego przetopienia. Zaobserwowano, że w trakcie procesu krzepnięcia powstała struktura komórkowa, a granice kryształów w wykonanym przetopieniu są gładkie (rys. 5a), co sprzyja silnej segregacji niskotopliwych składników bezpośrednio przyczyniających się do pękania gorącego w stanie stałym stopu. W wysokich temperaturach na gładkich granicach kryształów zachodzi również proces poślizgu, który prowadzi do międzykrystalicznego pękania zawsze w kierunku prostopadłym do działania naprężeń lub do powstających odkształceń skurczowych $[8,9]$. Odkształcenia skurczowe najprawdopodobniej doprowadziły do powstania mikroszczelin na graniach krystalitów, a te nie zostały usunięte w wyniku dopływającego ciekłego metalu, ponieważ proces krystalizacji zamknął jego dopływ. Widoczne są wolne przestrzenie między krystalitami, które powstały poprzez brak dostatecznej ilości cieczy, a także na skutek przyłożonego odkształcenia. Podczas analizy zaobserwowano, że na dnie pęknięcia istnieje struktura materiału rodzimego nadstopu niklu (rys. 5b), co sugeruje o propagacji pęknięcia w obszarze zakrzepniętego jeziorka spawalniczego.
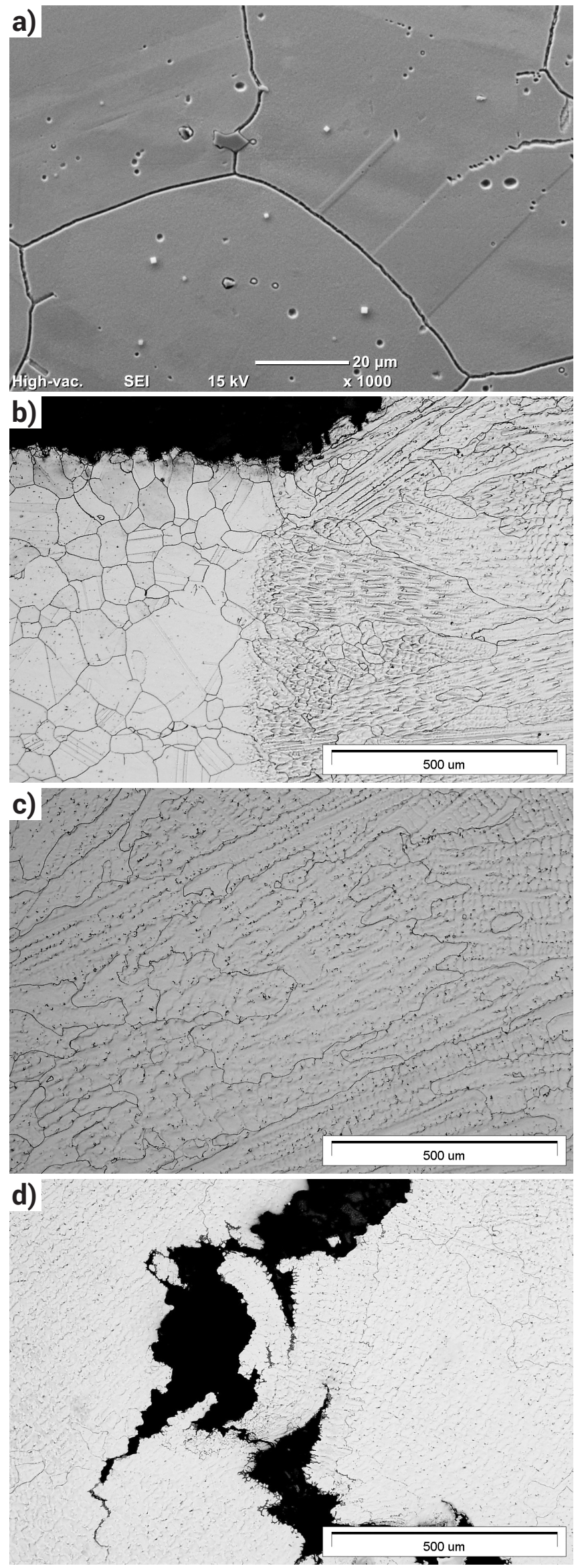

Rys. 4. Charakterystyczne obszary materiału Inconel 617 z miejsca pęknięcia w próbce IN_3_N: a) materiał rodzimy nadstopu niklu Inconel 617 , SEM; b) linia wtopienia, LM; c) struktura przetopienia, LM; d) miejsce pęknięcia, LM

Fig. 4. The characteristic areas of Inconel 617 from the place of crack in sample IN_3_N: a) native material of Inconel 617 superalloy, SEM; b) the weld line fusion, LM; c) the material of remelted weld, $\mathrm{LM}$; d) the location of the cracks in the remelted weld, LM 

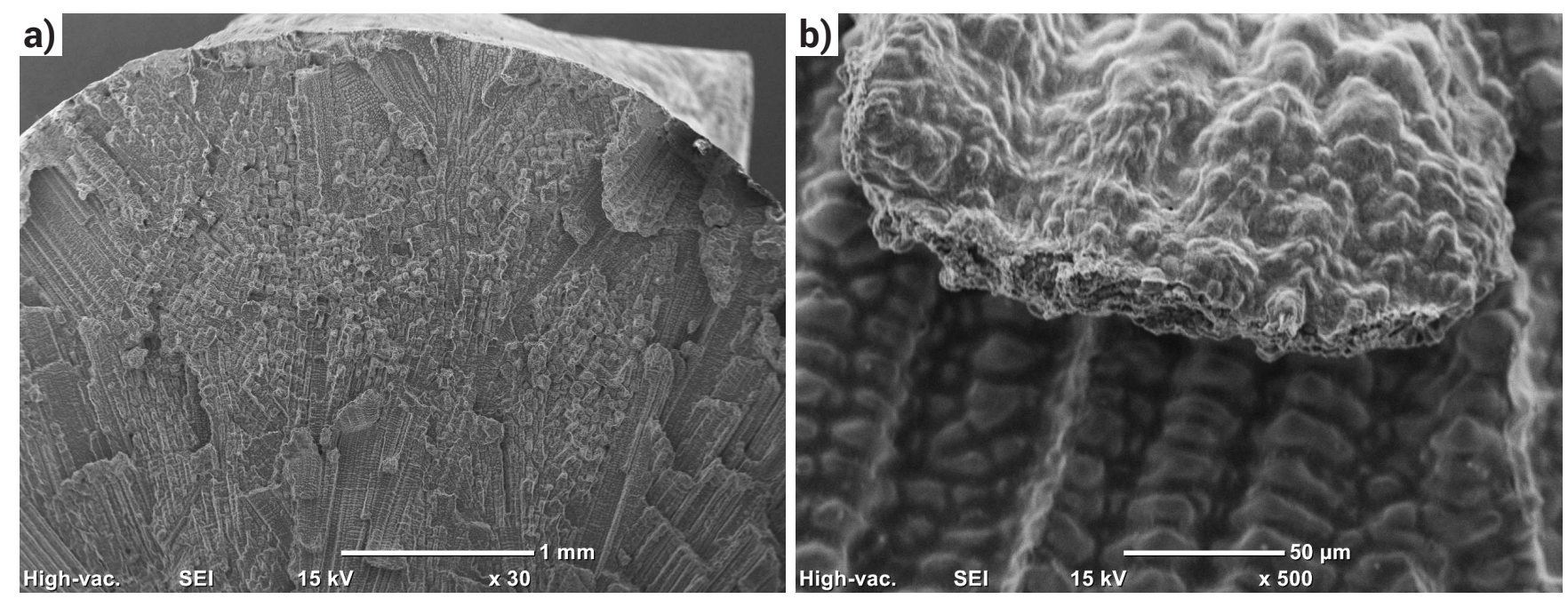

Rys. 5. Mikrostruktura pęknięcia gorącego, SEM: a) morfologia pęknięcia w napoinie; b) powierzchnia swobodna pęknięcia Fig. 5. The microstructure of hot cracking, SEM: a) the morphology of cracking in overlay weld; b) the crack free surface

Przeprowadzona mikroanaliza składu chemicznego EDS z obszaru pęknięcia (rys. 6) wykazała, iż na powierzchni tworzy się tlenek chromu, co potwierdza zwiększona zawartość obu pierwiastków. Pojawienie się tlenku chromu jest charakterystycznym zjawiskiem dla pękania gorącego.
Podwyższona zawartość węgla, molibdenu, niklu i chromu poza zainicjowanym pęknięciem może świadczyć o tworzeniu się na powierzchni nadstopu węglików M23C6, które tworzą drobnodyspersyjną eutektykę z fazą y.
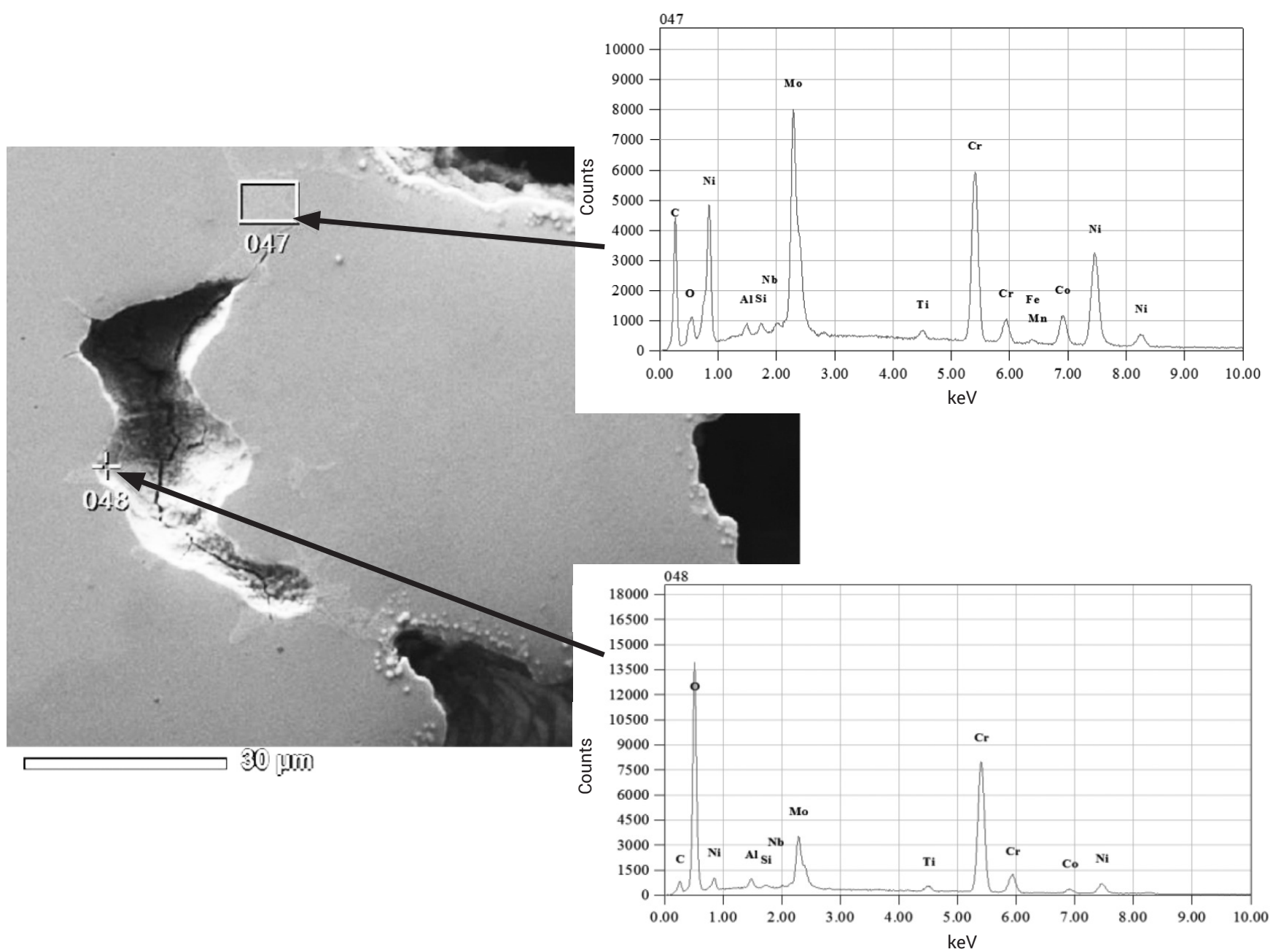

\begin{tabular}{|c|c|c|c|c|c|c|c|c|c|c|c|}
\hline Atom,\% & $\mathbf{A l}$ & $\mathbf{S i}$ & $\mathbf{C l}$ & $\mathbf{T i}$ & $\mathbf{C r}$ & $\mathbf{M n}$ & $\mathbf{F e}$ & $\mathbf{C o}$ & $\mathbf{N i}$ & $\mathbf{N b}$ & Mo \\
\hline $\mathbf{0 4 7}$ & 1,35 & 0,98 & - & 1,13 & 29,80 & 0,41 & 0,89 & 9,77 & 36,22 & 0,60 & 18,85 \\
\hline $\mathbf{0 4 8}$ & 3,12 & 0,61 & 0,15 & 1,91 & 66,31 & - & - & 4,11 & 11,34 & 0,47 & 11,98 \\
\hline
\end{tabular}

Rys. 6. Mikroanaliza składu chemicznego EDS wykonana na próbce z pęknięciem wyciętej prostopadle do osi napoiny

Fig. 6. The microanalysis of chemical composition EDS made on a sample with a crack cut perpendicular to the direction of overlay weld 


\section{Wnioski}

Na podstawie przeprowadzonych badań i analizy ich wyników sformułowano następujące wnioski:

- Nadstop niklu Inconel 617 w warunkach zmiennej sztywności wykazuje mniejszą skłonność do pękania gorącego podczas procesu przetapiania metodą TIG bez materiału dodatkowego niż z materiałem dodatkowym, co jest związane z mniejszymi naprężeniem i odkształceniem materiału. Niewątpliwie na podatność do pękania gorącego ma stopień czystości zastosowanego materiału dodatkowego. Stwierdzono, że najdłuższe pęknięcia występowały na początku procesu przetapiania, co może być związane z brakiem wstępnego podgrzewania nadstopu, co bezpośrednio przyczynia się do występowania dużych odkształceń. Wykazano, że w trakcie przetapiania bez materiału dodatkowego, skłonność do pęknięć gorących jest zminimalizowana o 40\%. Wyjątek stanowi płyta o grubości $1 \mathrm{~mm}$, w której nie zostały ujawnione pęknięcia. Wykonana napoina spełniła wymagania poziomu jakości B wg PN-EN ISO 5817:2014-05.

- Mikrostruktura osnowy y składa się z wydzieleń węglików bogatych w chrom i tytan. Nie zidentyfikowano pęknięć segregacyjnych w strefie wpływu ciepła. Zaobserwowano, że krystality w ściegu wykonanym z przetopieniem (bez materiału dodatkowego) narastają zgodnie z kierunkiem odprowadzonego ciepła.

- Bezpośrednią przyczyną powstania pękania gorącego, potwierdzonego w mikroanalizie składu chemicznego EDS przez podwyższoną obecność pierwiastków chromu i tlenu, było brak zwilżalności ciekłego metalu, co potwierdzają puste przestrzenie międzydendrytyczne. W badaniach fraktograficznych została ujawniona struktura komórkowa z narastającym płaskim frontem krystalizacji. Pęknięciom gorącym sprzyjają stosunkowo gładkie powierzchnie granic komórek i związana z tym mała powierzchnia właściwa granic krystalitów, na których występuje segregacja niskotopliwych składników.

- Przeprowadzone badania wykazały, iż zastosowanie przetapiania płyt próbnych metodą TIG bez materiału dodatkowego zmniejsza skłonność do pęknięć gorących w warunkach przeprowadzonych badań w porównaniu do przetapiania z materiałem dodatkowym.

\section{Literatura}

[1] Hernas A., Dobrzański J., Pasternak J., Fudali S.: Charakterystyki nowej generacji materiałów dla energetyki, Wydawnictwo Politechniki Śląskiej, Gliwice, 2015

[2] Adamiec J., Łyczkowska K., Tomaszewska A.: Wpływ technologii spawania laserowego na strukturę i właściwości złącza nadstopu niklu Inconel 625, Przegląd Spawalnictwa, nr 10, s. 81-83, 2015.

[3] Dul I., Jakubowski J., Senkara J.: Spajanie zaawansowanych stopów Ni w przemyśle lotniczym, Rudy i Metale Nieżelazne, nr 7-8, s. 397-405, 2011.

[4] Adamiec J.: Własności korozyjne napawanych warstw na elementach kotłów do spalania biomasy i odpadów komunalnych, w: Procesy niszczenia oraz powłoki ochronne stosowane w energetyce, s. 201-218, Słok k. Bechłatowa,12-13 marca 2015.

[5] Tuz L., Pańcikiewicz K., Tasak E., Adamiec J.: Badania skłonności do pęknięć gorących wybranych stopów niklu, Hutnik-Wiadomości Hutnicze, nr 4, s.162-169, 2016
[6] Liu W., Lu F., Yang R., Tang X., Cui H.: Gleeble simulation of the HAZ in Inconel 617 welding, Journal Materials Processing Technology, 225, pp. 221-228, 2015.

[7] Ren W., Lu F., Yang R., Liu X., Li Z.: Liquation cracking in fiber laser weIded joints of inconel 617, Journal Materials Processing Technology, 226, pp. 214-220, 2015.

[8] Tasak E.: Metalurgia spawania, Wydawnictwo JAK, Kraków 2008.

[9] Praca zbiorowa pod redakcją Jana Pilarczyka: Poradnik inżyniera. Spawalnictwo, tom 1-2, Wydawnictwo Naukowo-Techniczne, Warszawa, 2014.

[10] Adamiec J.: Spawalność odlewniczych stopów magnezu, Wydawnictwo Politechniki Śląskiej, Gliwice, 2010. 